\title{
Pengaruh Model Pembelajaran Berbasis Masalah Menggunakan Media Peta Konsep Terhadap Hasil Belajar Siswa Pada Materi Fluida Statis Di Kelas XI Semester II SMA Cerdas Murni T.P. 2014/2015
}

\author{
Juniar Hutahaean * dan Dae Sri Ardian ** \\ (Prodi Pendidikan Fisika FMIPA Unimed) \\ sriardiand@gmail.com \\ *) Dosen Fisika Unimed \\ **) Mahasiswa Pendidikan Fisika Unimed
}

\begin{abstract}
ABSTRAK
Penelitian ini bertujuan untuk mengetahui pengaruh model pembelajaran berbasis masalah menggunakan media peta konsep terhadap hasil belajar siswa. Jenis penelitian yang digunakan dalam penelitian ini adalah kuasi eksperimen dengan populasi dalam penelitian adalah seluruh siswa kelas XI SMA Cerdas Murni yang terdiri dari 3 kelas yaitu 118 siswa. Pengambilan sampel dilakukan dengan cara cluster random sampling dengan mengambil 2 kelas yaitu kelas XI-IPA 1 sebagai kelas eksperimen dan kelas XI-IPA 3 sebagai kelas kontrol dengan masingmasing jumlah siswa 39 orang. Berdasarkan hasil analisis data diperoleh nilai rata-rata hasil belajar siswa yang diberi perlakuan dengan model pembelajaran berbasis masalah menggunakan media peta konsep adalah 84 dan dengan pembelajaran konvensional adalah 77,46. Peningkatan aktivitas belajar siswa selama mengikuti pembelajaran dengan menggunakan model pembelajaran berbasis masalah menggunakan media peta konsep diperoleh rata-rata peningkatan aktivitas $\mathrm{N}$-gain siswa cukup baik dari pertemuan I ke pertemuan II sebesar 0,49 dengan kategori sedang dan dari pertemuan II ke pertemuan III sebesar 0,72 dengan kategori tinggi. Berdasarkan hasil analisis perhitungan uji t, terdapat perbedaan yang signifikan akibat pengaruh penerapan model pembelajaran berbasis masalah menggunakan media peta konsep terhadap hasil belajar siswa.
\end{abstract}

Kata Kunci : Model pembelajaran berbasis masalah, peta konsep, hasil belajar.

\begin{abstract}
The purpose of this research are to find out the effect of application of problembased learning model using the media concept maps to student learning outcomes. The study was quasi-experimental with the entire population of eleventh grade students of SMA Cerdas Murni consisting of three classes that aggregate 118 students. Samples were taken 2 classes are determined by random cluster sampling technique, the class XI-1 as experiment class and class XI-3 as ontrol class with 39 students. The average value of student learning outcomes treated with problem based learning model by using the concept maps media is 84 and
\end{abstract}


with conventional learning is 77,46. The increased activity of learning during follow the learning with problem based learning model by using the concept maps media with activity $N$-Gain for one and two meeting is 0,49 which include to medium criteria and activity for two and three meeting is 0,72 which include to high criteria. Based on the results of the calculation of t test analysis, there are significant differences due to the effect of application of problem based learning model assisted the concept maps media to students learning outcomes.

Key Words : Problem Based Learning model, concept maps, learning outcomes.

\section{PENDAHULUAN}

Pendidikan bagi bangsa yang sedang membangun seperti bangsa Indonesia saat ini merupakan kebutuhan mutlak yang harus dikembangkan sejalan dengan tuntutan pembangunan secara tahap demi tahap. Pendidikan yang dikelola dengan tertib, teratur, efektif dan efisien (berdaya guna dan berhasil guna) akan mampu mempercepat jalannya proses pembudayaan bangsa yang berdasarkan pokok pada penciptaan kesejahteraan umum dan pencerdasan kehidupan bangsa Indonesia. Sehubungan dengan hal tersebut komisi tentang pendidikan abad ke-21 merekomendasikan empat strategi dalam mensukseskan pendidikan: Pertama, learning to learn yaitu memuat bagaimana siswa mampu menggali informasi yang ada di sekitarnya dari ledakan informasi itu sendiri. Kedua, learning to be yaitu siswa diharapkan mampu untuk mengenali dirinya sendiri serta mampu beradaptasi dengan lingkungannya. Ketiga, learning to do yaitu berupa tindakan atau aksi untuk memunculkan ide yang berkaitan dengan sains. Keempat, learning to be together yaitu memuat bagaimana hidup dalam masyarakat yang saling bergantung antara satu dengan yang lain sehingga mampu bersaing secara sehat dan bekerja sama seperti mampu menghargai orang lain (Trianto, 2011).

Pendidikan memiliki peranan penting dalam kehidupan berbangsa dan bernegara dalam mewujudkan tujuan kehidupan berbangsa yang aman, damai dan sejahtera. Fungsi dan tujuan pendidikan nasional lebih jelasnya tertuang dalam UndangUndang Nomor: 2 Tahun 1989 yaitu: "Mencerdaskan kehidupan bangsa dan mengembangkan manusia Indonesia seutuhnya, yaitu manusia yang beriman dan bertakwa terhadap Tuhan Yang Maha Esa dan berbudi pekerti yang luhur, memiliki pengetahuan dan keterampilan, kesehatan jasmani dan rohani, kepribadian yang mantap dan mandiri serta rasa tanggung jawab kemasyarakatan dan kebangsaan" (Hasbullah, 2005).

Salah satu pendidikan yang perlu mendapat perhatian adalah ilmu pengetahuan alam. Fisika merupakan bagian dari ilmu pengetahuan alam (IPA) yang merupakan suatu kumpulan pengetahuan yang tersusun secara sistematis, dan dalam penggunaannya secara umum terbatas pada gejala-gejala alam. Namun, kebanyakan siswa selalu menganggap bahwa IPA, terutama fisika, merupakan pelajaran yang sulit. Hal ini menyebabkan rendahnya nilai ujian siswa pada pelajaran fisika. 
Kenyataan ini sesuai dengan hasil studi pendahuluan peneliti dengan melakukan wawancara kepada guru fisika kelas XI SMA Cerdas Murni, Bapak Syarief, diperoleh data hasil belajar fisika siswa yang pada umumnya masih di bawah rata-rata yaitu 65 sedangkan Kriteria Ketuntasan Minimal (KKM) yang harus dicapai adalah 75. Sehingga dapat dikatakan nilai rata-rata siswa tidak mencapai kriteria yang diharapkan. Adapun faktor penyebab rendahnya hasil belajar siswa yaitu, selama melakukan proses pembelajaran, guru hanya menekankan pada berjalannya silabus sehingga siswa tidak ketinggalan pelajaran dan pembelajaran yang digunakan yang secara umum masih berpusat pada guru. Guru juga tidak melakukan variasi-variasi dalam proses pembelajaran seperti penggunaan media, model pembelajaran, dan penggunaan laboratorium padahal sekolah tersebut memiliki sarana dan prasarana yang memadai untuk mendukung pembelajaran yang lebih baik guna menunjang pemahaman siswa tentang materi pembelajaran sehingga kompetensi yang diharapkan bisa tercapai.

Adapun faktor lainnya adalah pelajaran fisika sering kali disajikan dalam bentuk persamaan matematik dan mengutamakan perhitungan dari pada penjelasan konsep fisikanya, sehingga siswa sering hanya dapat menghitung tetapi tidak mengerti konsep fisikanya. Hal ini diduga sebagai penyebab ketidakmampuan siswa untuk menerapkan konsepkonsep fisika itu dalam kehidupan sehari-hari. Konsep-konsep fisika tersebut akan terasa asing dalam kehidupan siswa dan akan mengurangi minat siswa untuk belajar fisika (Simarmata, 2010).

Berdasarkan berbagai masalah di atas, perlu adanya upaya yang dilakukan oleh guru, salah satu solusinya dengan menerapkan model pembelajaran berbasis masalah. Model pembelajaran berbasis masalah adalah pola pembelajaran yang menghadapkan siswa pada masalah nyata yang dijumpai dalam kehidupan sehari-hari dan membantu siswa mengembangkan keterampilan berpikir dan keterampilan memecahkan masalah. Pembelajaran berbasis masalah merupakan pendekatan yang efektif untuk pengajaran proses berpikir tingkat tinggi (Trianto, 2010).

Model pembelajaran berbasis masalah ini sudah pernah diteliti oleh beberapa peneliti sebelumnya diantaranya, Gafar dan Ridwan (2008) dan Pandu (2013) yang kemudian dari kedua penelitian tersebut dapat disimpulkan bahwa ada pengaruh yang signifikan antara model pembelajaran berdasarkan masalah terhadap hasil belajar siswa hasil pembelajaran berbasis masalah cukup baik.

Berdasarkan uraian masalah di atas, tujuan dari penelitian ini adalah: (1) Untuk mengetahui hasil belajar siswa dengan menggunakan pembelajaran berbasis masalah pada materi fluida statis di kelas XI semester II SMA Cerdas Murni T.P. 2014/2015. (2) Untuk mengetahui hasil belajar siswa dengan menggunakan pembelajaran konvensional pada materi fluida statis di kelas XI semester II SMA Cerdas Murni T.P. 2014/2015. (3) Untuk mengetahui aktivitas belajar siswa menggunakan model pembelajaran berbasis masalah menggunakan media peta konse $p$ pada materi pokok 
fluida statis di kelas XI semester II SMA Cerdas Murni T.P. 2014/2015 .

(4) Untuk mengetahui pengaruh model pembelajaran berbasis masalah menggunakan media peta konsep terhadap hasil belajar siswa pada materi fluida statis di kelas XI semester II SMA Cerdas Murni T.P. 2014/2015.

\section{METODE PENELITIAN}

Penelitian dilaksanakan di SMA Cerdas Murni kelas XI semester II T.P. 2014/2015 yang beralamat di jalan beringin pasar VII Tembung, Kecamatan Percut Sei Tuan, Deli Serdang. Populasi dalam penelitian ini adalah seluruh siswa kelas XI semester II peminatan ilmu alam SMA Cerdas Murni T.P. 2014/2015, yang terdiri dari tiga kelas.

Teknik pengambilan sampel dilakukan dengan cara teknik sampel kelas acak (cluster random sampling). Sampel diambil dari populasi yaitu sebanyak dua kelas. Satu kelas dijadikan sebagai kelas ekperimen dengan jumlah siswa sebanyak 39 orang diajar dengan model pembelajaran berbasis masalah menggunakan media peta konsep dan satu kelas lagi dijadikan sebagai kelas kontrol dengan jumlah siswa sebanyak 39 orang yang diajar dengan pembelajaran konvensional. Jenis penelitian ini adalah kuasi eksperimen ini dengan desain two group pretest-postest design seperti yang ditunjukkan pada Tabel 1.

Tabel 1. Tabel Penelitian tipe PretestPostest Control Group Design

\begin{tabular}{|l|c|c|c|}
\hline \multicolumn{1}{|c|}{ Kelas } & Pretest & Perlakuan & Postes \\
\hline Eksperimen & $\mathrm{T}_{1}$ & $\mathrm{X}$ & $\mathrm{T}_{2}$ \\
Kontrol & $\mathrm{T}_{1}$ & $\mathrm{Y}$ & $\mathrm{T}_{2}$ \\
\hline
\end{tabular}

Keterangan :

$\mathrm{T}_{1}=$ Pemberian tes awal (pre-tes)

$\mathrm{T}_{2}=$ Pemberian tes akhir (pos-tes)
$\mathrm{X}=$ Perlakuan dengan model pembelajaran berbasis masalah

$\mathrm{Y}=$ Perlakuan dengan model pembelajaran konvensional

Alat pengumpul data dalam penelitian ini adalah tes berbentuk uraian untuk mengetahui hasil belajar siswa pada ranah kognitif dan lembar observasi untuk mengetahui aktivitas siswa.

Uji hipotesis yang digunakan dengan menggunakan uji $t$ dengan membandingkan rata-rata skor hasil belajar yang dicapai baik kelas eksperimen maupun kelas kontrol. Data yang diperoleh ditabulasikan kemudian dicari rata-ratanya. Sebelum dilakukan penganalisisan data, terlebih dahulu ditentukan skor masing-masing kelompok sampel lalu dilakukan pengolahan data.

Peningkatan hasil belajar dengan menggunakan $\mathrm{N}$-gain yang dinormalisasi (Meltzer, 2002). Karena dalam penilaian aktivitas siswa ada tiga tahapan, maka dapat dihitung dengan rumus yang digunakan adalah:

$$
\begin{aligned}
& \mathrm{g}=\frac{\vec{X}_{2}-\vec{X}_{1}}{\vec{X}_{m}-\vec{X}_{1}} \\
& \mathrm{~g}=\frac{\vec{X}_{3}-\vec{X}_{2}}{\vec{X}_{m}-\vec{X}_{2}}
\end{aligned}
$$

Keterangan :

$\overline{\mathrm{X}}_{1}=$ rata-rata aktivitas siswa tahap 1

$\overline{\mathrm{X}}_{2}=$ rata-rata aktivitas siswa tahap 2

$\overline{\mathrm{X}}_{3}=$ rata-rata aktivitas siswa tahap 3

$\overline{\mathrm{X}}_{\mathrm{m}}=$ rata-rata skor maksimum

\section{HASIL PENELITIAN DAN PEMBAHASAN}

\section{a. Hasil Penelitian}

Penelitian diawali dengan memberikan kedua kelas tes uji kemampuan awal (pretes) yang bertujuan untuk mengetahui apakah kemampuan awal siswa pada kedua kelas sama atau tidak. Hasil pretes 
kelas eksperimen memperoleh nilai rata-rata 38 dan nilai rata-rata kelas kontrol adalah 36. Setelah memperoleh data pretes siswa, maka dilakukan pengujian analisis data dengan menggunakan uji kesamaan rata-rata pretes dimana syaratnya data harus berdistribusi normal dan homogen. Hasil uji normalitas data pretes ditunjukkan pada Tabel 2.

Tabel 2. Uji Normalitas Data Pretes

\begin{tabular}{|c|c|c|c|c|}
\hline $\begin{array}{l}\mathrm{N} \\
\mathrm{O}\end{array}$ & Data & Lhitung & $\mathrm{L}_{\text {tabel }}$ & $\begin{array}{l}\text { Kesim } \\
\text { pulan }\end{array}$ \\
\hline 1 & $\begin{array}{l}\text { Pretes } \\
\text { Kelas } \\
\text { Eksperimen }\end{array}$ & $\begin{array}{l}0,135 \\
2\end{array}$ & \multirow{2}{*}{0,14} & \multirow{2}{*}{$\begin{array}{l}\text { Nor } \\
\text { mal }\end{array}$} \\
\hline 2 & $\begin{array}{l}\text { Pretes } \\
\text { Kelas } \\
\text { Kontrol }\end{array}$ & $\begin{array}{l}0,130 \\
8\end{array}$ & & \\
\hline
\end{tabular}

Tabel 2. menunjukkan bahwa $\mathrm{L}_{\text {hitung }}<\mathrm{L}_{\text {tabel }}$ baik kelas eksperimen dan kelas kontrol dengan $\alpha=0,05$, sehingga dapat disimpulkan bahwa data berdistribusi normal.

Tabel 3. Uji Homogenitas Data Pretes

\begin{tabular}{|c|c|c|c|c|c|}
\hline $\begin{array}{c}\mathrm{N} \\
\mathrm{o}\end{array}$ & \multicolumn{1}{|c|}{ Data } & $\begin{array}{l}\text { Vari } \\
\text { ans }\end{array}$ & $\mathrm{F}_{\text {hitung }}$ & $\mathrm{F}_{\text {tabel }}$ & $\begin{array}{l}\text { Kesim } \\
\text { pulan }\end{array}$ \\
\hline 1 & $\begin{array}{l}\text { Pretes Kelas } \\
\text { Eksperimen }\end{array}$ & 144,9 & 1,38 & 1,72 & $\begin{array}{l}\text { Hom } \\
\text { ogen }\end{array}$ \\
\hline 2 & $\begin{array}{l}\text { Pretes Kelas } \\
\text { Kontrol }\end{array}$ & 105,1 & 1,38 & \\
\hline
\end{tabular}

Tabel 3. menunjukkan bahwa $\mathrm{F}_{\text {hitung }}<\mathrm{F}_{\text {tabel }}$ yaitu $1,38<1,72$ dengan $\alpha$ $=0,05$, maka dapat disimpulkan bahwa data pretes kelas eksperimen memiliki varians yang sama dengan kelas kontrol (homogen).

Tabel 4. Uji Hipotesis Data Pretes

\begin{tabular}{|c|c|c|c|c|c|}
\hline $\begin{array}{c}\mathrm{N} \\
\mathrm{o}\end{array}$ & Data & $\begin{array}{c}\text { Nilai } \\
\text { Rata- } \\
\text { rata }\end{array}$ & $\mathrm{t}_{\text {hitung }}$ & $\mathrm{t}_{\text {tabel }}$ & $\begin{array}{l}\text { Kesim } \\
\text { pulan }\end{array}$ \\
\hline 1 & $\begin{array}{l}\text { Pretes Kelas } \\
\text { Eksperimen }\end{array}$ & 38 & 0,79 & $\begin{array}{l}1,9 \\
9\end{array}$ & $\begin{array}{l}\text { Ho } \\
\text { diteri } \\
\text { ma }\end{array}$ \\
\hline 2 & $\begin{array}{l}\text { Pretes Kelas } \\
\text { Kontrol }\end{array}$ & 36 & \\
\hline
\end{tabular}

Berdasarkan Tabel 4, perhitungan uji kesamaan nilai rata-rata pretes kelas eksperimen dan kelas kontrol untuk $\alpha=0,05, \mathrm{t}_{\text {hitung }}<\mathrm{t}_{\text {tabel }}$ yaitu 0,79 $<1,99$, sehingga dapat disimpulkan bahwa kemampuan awal siswa pada kelas eksperimen sama dengan kemampuan awal siswa pada kelas kontrol.

Tabel 5. Uji Normalitas Data Postes

\begin{tabular}{|c|c|c|c|c|}
\hline $\begin{array}{l}\mathrm{N} \\
\mathrm{O}\end{array}$ & Data & $L_{\text {hitung }}$ & $\mathrm{L}_{\text {tabel }}$ & $\begin{array}{l}\text { Kesim } \\
\text { Pulan }\end{array}$ \\
\hline 1 & $\begin{array}{l}\text { Postes Kelas } \\
\text { Eksperimen }\end{array}$ & 0,128 & \multirow{2}{*}{0,14} & \multirow{2}{*}{ Normal } \\
\hline 2 & $\begin{array}{l}\text { Postes Kelas } \\
\text { Kontrol }\end{array}$ & 0,116 & & \\
\hline
\end{tabular}

Tabel 5. menunjukkan bahwa $\mathrm{L}_{\text {hitung }}<\mathrm{L}_{\text {tabel }}$ baik kelas eksperimen dan kelas kontrol dengan $\alpha=0,05$, sehingga dapat disimpulkan bahwa data berdistribusi normal.

Tabel 6. Uji Homogenitas Data Postes

\begin{tabular}{|c|c|c|c|c|c|}
\hline $\begin{array}{c}\mathrm{N} \\
\mathrm{o}\end{array}$ & Data & $\begin{array}{l}\text { Vari } \\
\text { ans }\end{array}$ & $\mathrm{F}_{\text {hitung }}$ & $\mathrm{F}_{\text {tabel }}$ & $\begin{array}{l}\text { Kesim } \\
\text { pulan }\end{array}$ \\
\hline 1 & $\begin{array}{l}\text { Postes Kelas } \\
\text { Eksperimen }\end{array}$ & 49,42 & 1,59 & 1,72 & $\begin{array}{l}\text { Hom } \\
\text { ogen }\end{array}$ \\
\hline 2 & $\begin{array}{l}\text { Postes Kelas } \\
\text { Kontrol }\end{array}$ & 30,94 & 1,59 & \\
\hline
\end{tabular}

Tabel 6. menunjukkan bahwa $\mathrm{F}_{\text {hitung }}<\mathrm{F}_{\text {tabel }}$ yaitu $1,59<1,72$ dengan $\alpha$ $=0,10$, maka dapat disimpulkan bahwa data postes kelas eksperimen memiliki varians yang sama dengan kelas kontrol (homogen).

Tabel 7. Uji Hipotesis Data Postes

\begin{tabular}{|c|c|c|c|c|c|}
\hline $\begin{array}{c}\mathrm{N} \\
\mathrm{O}\end{array}$ & Data & $\begin{array}{c}\text { Nilai } \\
\text { Rata- } \\
\text { rata }\end{array}$ & $\mathrm{t}_{\text {hitung }}$ & $\mathrm{t}_{\text {tabel }}$ & $\begin{array}{c}\text { Kesimpu } \\
\text { lan }\end{array}$ \\
\hline 1 & $\begin{array}{l}\text { Postes Kelas } \\
\text { Eksperimen }\end{array}$ & 84 & \multirow{2}{*}{4,7} & 1,6 & $\begin{array}{c}\mathrm{H}_{\mathrm{a}} \\
\text { diterima }\end{array}$ \\
\cline { 1 - 3 } 2 & $\begin{array}{l}\text { Postes Kelas } \\
\text { Kontrol }\end{array}$ & 77,46 & 4,7 \\
\hline
\end{tabular}


Berdasarkan Tabel 7, kelas eksperimen yang diajarkan dengan model pembelajaran berbasis masalah menggunakan media peta konsep memperoleh nilai rata-rata hasil belajar sebesar 84 dan kelas kontrol yang diajarkan dengan model konvensional memperoleh hasil belajar dengan ratarata hasil belajar sebesar 77,46. Data di atas menunjukkan bahwa $t_{\text {hitung }}>t_{\text {tabel }}$ yaitu(4,70 > 1,6), sehingga dapat disimpulkan bahwa ada pengaruh model pembelajaran berbasis masalah menggunakan media peta konsep terhadap hasil belajar siswa pada materi pokok fluida statis di kelas XI semester genap SMA Cerdas Murni T.P 2014/2015.

Selama proses pembelajaran, peningkatan aktivitas siswa sangat penting diperhatikan karena pada hakekatnya belajar merupakan perubahan tingkah laku yang menyangkut pengetahuan dan keterampilan. Keterampilan yang dimaksud adalah keterampilan menunjukkan masalah, merumuskan hipotesis, mengidentifikasi masalah, menganalisis masalah, memecahkan masalah, dan mempresentasikan hasil karya. Dalam penelitian ini peningkatan yang terjadi setiap pembelajaran dihitung dengan rumus N-Gain. Hasil penilaian peningkatan aktivitas siswa dapat dilihat pada Gambar 1.

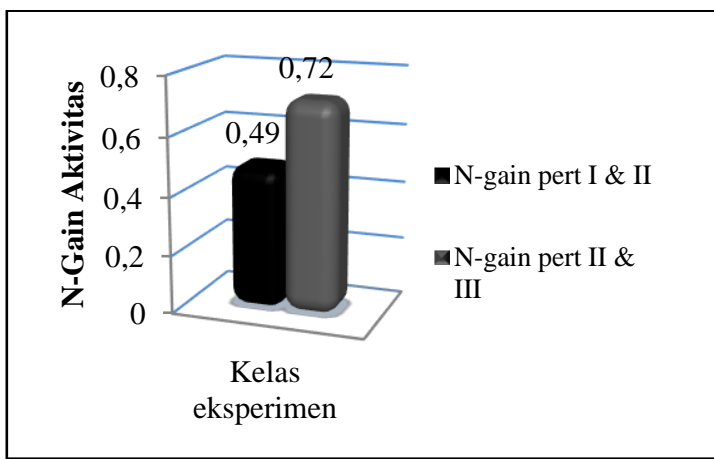

Gambar 1. Diagram Batang Rata-rata Peningkatan Aktivitas Belajar Siswa
Berdasarkan Gambar 1 dapat dilihat bahwa terjadi peningkatan aktivitas pada setiap pertemuan. Ratarata nilai gain dari pertemuan I ke pertemuan II sebesar 0,49 dengan kategori sedang dan dari pertemuan II ke pertemuan III sebesar 0,72 dengan kategori tinggi. Hal ini menunjukkan bahwa siswa semakin aktif dalam proses belajar mengajar.

\section{b. Pembahasan}

Hasil penelitian menunjukkan bahwa ada pengaruh penerapan model pembelajaran berbasis masalah menggunakan media peta konsep terhadap hasil belajar siswa pada materi fluida statis di kelas XI semester II SMA Cerdas Murni T.P.2014/2015. Hal ini diperkuat dengan adanya perbedaan hasil belajar siswa yang dapat dilihat dari hasil postes kelas eksperimen yang memperoleh rata-rata nilai 84 , sedangkan hasil postes di kelas kontrol memperoleh rata-rata 77,46.

Kelas eksperimen yang diberikan perlakuan dengan menerapkan model pembelajaran berbasis masalah menggunakan media peta konsep memperoleh hasil belajar ranah kognitif siswa berbeda dengan kelas kontrol yang diajarkan dengan model pembelajaran konvensional yang sebelumnya telah diketahui memiliki kesamaan kemampuan awalnya yaitu 38 untuk kelas eksperimen dan 36 untuk kelas kontrol dengan thitung < $t_{\text {tabel }}$ yaitu $0,79<1,99$. Kemampuan akhir siswa dapat dilihat dengan memberikan postes terhadap kedua kelas. Hasil belajar yang diperoleh adalah nilai rata-rata hasil belajar untuk kelas eksperimen adalah 84 sedangkan untuk kelas kontrol adalah 77,46 dengan $t_{\text {hitung }}>t_{\text {tabel }} 4,7>1,6$. Berdasarkan data tersebut, dapat disimpulkan bahwa ada pengaruh 
model pembelajaran berbasis masalah terhadap hasil belajar siswa pada materi fluida statis di kelas XI SMA Cerdas Murni TP.2014/1015.

$$
\text { Adanya perbedaan hasil }
$$

belajar ranah kognitif tersebut disebabkan oleh kelebihan model pembelajaran berbasis masalah yang salah satunya pembelajaran berdasarkan masalah merupakan teknik yang cukup bagus untuk lebih memahami isi pelajaran dan membantu siswa bagaimana mentransfer pengetahuan mereka untuk memahami masalah dalam kehidupan nyata. Model pembelajaran berbasis masalah mempunyai tiga konsep utama yaitu pengetahuan yang didapat dari proses penyelidikan autentik yang berupa masalah, siswa dapat mengembangkan kemampuan untuk menyimpulkan dari penyelidikan yang telah dilakukan (knowledge) dan siswa menganalisis unsur-unsur yang diperlukan, dalam melaksanakan percobaan. Hal ini juga didukung oleh teori konstruktivisme bahwa dalam model pembelajaran ini pengetahuan dibangun oleh siswa sendiri secara aktif baik melalui proses personal maupun sosial. Teori konstruktivis sesuai dengan model pembelajaran berbasis masalah yang mengharuskan siswa melakukan penyelidikan autentik untuk mencari penyelesaian nyata terhadap masalah nyata. Mereka harus menganalisis dan mendefinisikan masalah, mengembangkan hipotesi, dan membuat ramalan, mengumpul dan menganalisa informasi, melakukan eksperimen (jika diperlukan), membuat inferensi, dan merumuskan kesimpulan. Sudah barang tentu, metode penyelidikan yang digunakan, bergantung kepada masalah yang sedang dipelajari.
Pembelajaran berbasis masalah menggunakan media peta konsep dapat juga meningkatkan aktivitas belajar siswa, hal ini ditunjukkan dari hasil observasi aktivitas belajar siswa, mulai pertemuan I sampai pertemuan III. Hasil pengamatan yang dilakukan oleh observer di kelas eksperimen diperoleh bahwa aktivitas siswa mengalami peningkatan yang positif. Rata-rata nilai gain dari pertemuan I ke pertemuan II sebesar 0,49 dengan kategori sedang dan dari pertemuan II ke pertemuan III sebesar 0,72 dengan kategori tinggi. Hal ini menunjukkan bahwa siswa semakin aktif dalam proses belajar mengajar. Aktivitas merupakan prinsip atau asas yang penting di dalam interaksi belajar dan mengajar. Aktivitas belajar adalah aktivitas yang bersifat fisik ataupun mental yang saling berkaitan. Belajar pada prinsipnya adalah berbuat. Berbuat untuk mengubah tingkah laku, jadi melakukan kegiatan. Keaktifan siswa di kelas eksperimen dengan kategori aktif dipengaruhi oleh adanya faktor yang mendukung yaitu penggunaan model pembelajaran. Model pembelajaran berbasis masalah memiliki kelebihan yang salah satunya meningkatkan aktivitas pembelajaran siswa (Sanjaya, 2010). Penggunaan model pembelajaran berbasis masalah prinsipnya berpusat pada siswa (student centered), sehingga siswa yang lebih banyak berperan dan lebih aktif dalam proses pembelajaran.

\section{KESIMPULAN DAN SARAN}

\section{a. Kesimpulan}

Berdasarkan hasil penelitian yang diperoleh dari hasil analisa data dapat disimpulkan sebagai berikut : (1) Ada pengaruh yang signifikan dari model pembelajaran berbasis masalah 
menggunakan media peta konsep terhadap hasil belajar siswa pada materi fluida statis di kelas XI semester II SMA Cerdas Murni T.P. 2014/2015. (2) Hasil belajar siswa dengan menggunakan model pembelajaran berbasis masalah menggunakan media peta konsep pada materi fluida statis di kelas XI semester II SMA Cerdas Murni T.P 2014/2015, diperoleh nilai rata-rata pretes sebesar 38 dan nilai rata-rata postes sebesar 84. (3) Hasil belajar siswa dengan menggunakan model pembelajaran konvensional pada materi fluida statis di kelas XI semester II SMA Cerdas Murni T.P 2014/2015, diperoleh nilai rata-rata pretes sebesar 36 dan nilai rata-rata postes sebesar 77,46. (4) Hasil observasi aktivitas belajar siswa setelah menerapkan model pembelajaran berbasis masalah menggunakan media peta konsep diperoleh nilai dari pertemuan I ke II terjadi rata-rata peningkatan $\mathrm{N}$-gain sebesar 0,49 dengan kategori sedang, dan dari pertemuan II ke III rata-rata peningkatan $\mathrm{N}$-gain sebesar 0,72 dengan kategori tinggi.

\section{b. Saran}

Berdasarkan hasil dan kesimpulan dalam penelitian ini, maka peneliti mempunyai beberapa saran, yaitu : (1) Bagi peneliti selanjutnya yang ingin melakukan penelitian dengan menggunakan model pembelajaran berbasis masalah, sebaiknya menguasai terlebih dahulu setiap sintaks yang terdapat dalam model, supaya kegiatan pembelajaran dapat berlangsung dengan baik. (2) Bagi peneliti selanjutnya hendaknya harus lebih tegas lagi dalam mengonrol kelas saat melaksanakan diskusi kelompok sehingga kelas menjadi lebih kondusif. (3) Bagi peneliti selanjutnya hendaknya lebih memahami bagaimana mengambil masalah yang layak dijadikan masalah dalam pembelajaran berbasis masalah untuk dipecahkan oleh siswa yang akan diberi perlakuan. (4) Bagi peneliti selanjutnya yang ingin meneliti model pembelajaran berbasis masalah lebih lanjut, disarankan untuk memperhatikan efisiensi waktu sehingga semua sintaks efektif saat pelaksanaan proses pembelajaran.

\section{DAFTAR PUSTAKA}

Abdullah, A. G., dan Ridwan, T., (2008) Implementasi Problem Based Learning (PBL) pada Proses Pembelajaran di BPTP Bandung http://ejournal.umm.ac.id/inde x.php/ips/article/viewFile/195 $\underline{0 / 2050}$

Hasbullah., (2005), Dasar-dasar Ilmu Pendidikan, Raja Grafindo Persada, Jakarta.

Meltzer, D. E., (2002), “The Relationshif between Mathematics Preparation and Conceptual Learning Gain in Physics: A Possible Hidden Variable in Diagnostic Pretest Score". Am, J. Phys.70,(2), 1259-1267.

Pandu, L., (2013) Penerapan Model Problem Based Learning untuk Meningkatkan Keaktifan Dan Hasil Belajar Siswa Pada Pelajaran Komputer (KK6) di SMK N 2 Wonosari Yogyakarta: http://eprints.uny.ac.id/10413/ 1/jurnal.pdf 
Sanjaya, W., (2010), Strategi Pembelajaran Berorientasi Standar Proses Pendidikan, Kencana Prenada Media Group, Jakarta.

Simarmata, U., (2010), Pengaruh Pembelajaran Kooperatif Tipe TPS (Think-Pair-Share) terhadap Hasil Belajar Siswa pada Pokok Bahasan Listrik Statis Kelas IX Semester I di SMP Negeri 4 Medan, Jurnal penelitian bidang pendidikan, 16 (1): 18-24.

Trianto., (2011), Mendesain Model Pembelajaran Inovatif Progresif, Kencana, Jakarta. 